
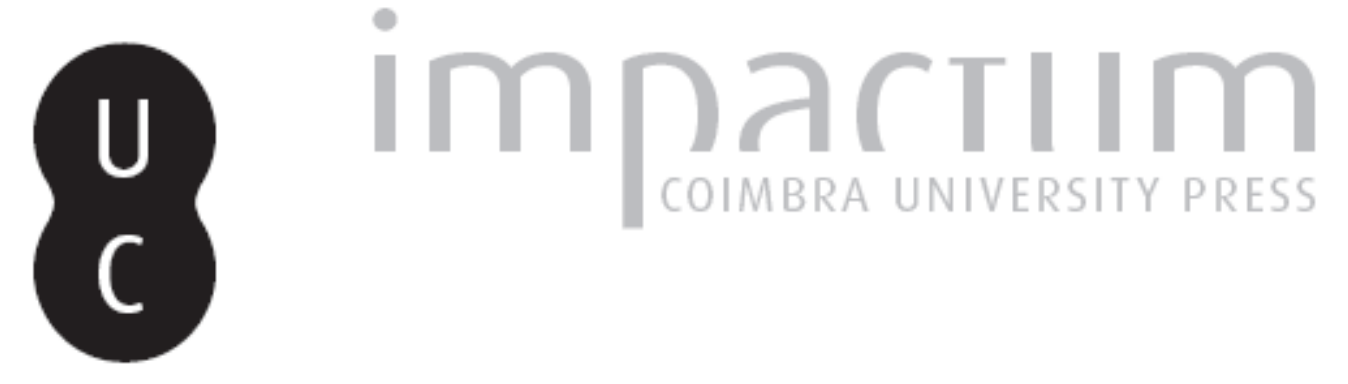

\title{
Considerações sobre o Al-Farabi de Leo Strauss
}

\section{Autor(es): $\quad$ Abranches, André}
Publicado por: Faculdade de Letras da Universidade de Coimbra, Instituto de Estudos Filosóficos

URL

persistente:

URI:http://hdl.handle.net/10316.2/33420

DOI:

DOI:http://dx.doi.org/10.14195/0872-0851_43_2

Accessed : $\quad$ 26-Apr-2023 06:31:35

A navegação consulta e descarregamento dos títulos inseridos nas Bibliotecas Digitais UC Digitalis, UC Pombalina e UC Impactum, pressupõem a aceitação plena e sem reservas dos Termos e Condições de Uso destas Bibliotecas Digitais, disponíveis em https://digitalis.uc.pt/pt-pt/termos.

Conforme exposto nos referidos Termos e Condições de Uso, o descarregamento de títulos de acesso restrito requer uma licença válida de autorização devendo o utilizador aceder ao(s) documento(s) a partir de um endereço de IP da instituição detentora da supramencionada licença.

Ao utilizador é apenas permitido o descarregamento para uso pessoal, pelo que o emprego do(s) título(s) descarregado(s) para outro fim, designadamente comercial, carece de autorização do respetivo autor ou editor da obra.

Na medida em que todas as obras da UC Digitalis se encontram protegidas pelo Código do Direito de Autor e Direitos Conexos e demais legislação aplicável, toda a cópia, parcial ou total, deste documento, nos casos em que é legalmente admitida, deverá conter ou fazer-se acompanhar por este aviso.

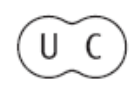




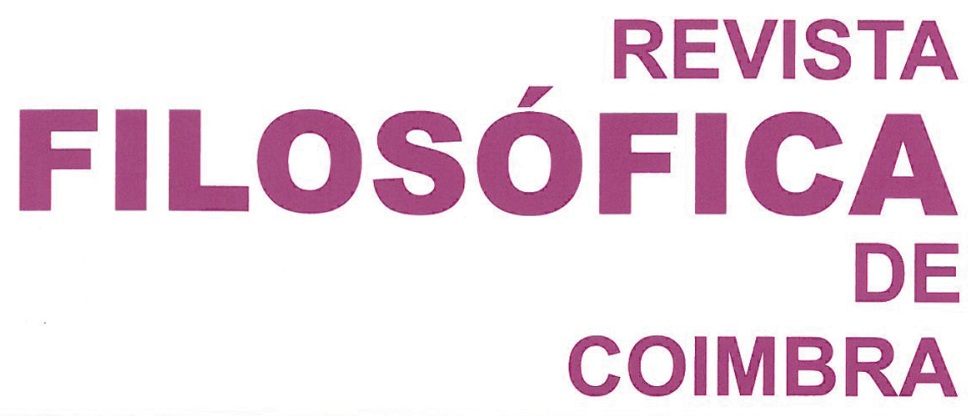

vol. 22 - número 43 - março 2013

vol. 22 - número 43 - março 2013

Fundação Eng. António de Almeida

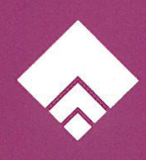




\title{
CONSIDERAÇÕES SOBRE O AL-FARABI DE LEO STRAUSS
}

\author{
ANDRÉ ABRANCHES
}

Resumo: Este artigo pretende investigar a questão da verdadeira natureza da filosofia política de Al-Farabi. Para esse efeito - e depois de se efectuar uma breve introdução sobre o estado de arte -, procurou-se compreender a controversa e poderosíssima tese de Leo Strauss - o grande percursor contemporâneo dos estudos sobre Farabi. Procurámos demonstrar que para Strauss, Farabi era essencialmente platónico; melhor, um verdadeiro platonista: aquele que compreendeu, conservou e reproduziu a verdadeira natureza da filosofia platónica. Segundo Strauss, Farabi seria um verdadeiro platonista por dotar, à imagem do seu Platão, a sua filosofia de uma forma peculiar: de uma forma política. A forma política da filosofia é assim o primeiro significado da filosofia de Farabi, o mais imediato, mas não o último. Neste sentido, Farabi entenderia a forma política da filosofia como um processo platónico de auto-consciência que recai sobre a filosofia socrática. Se a filosofia socrática for já uma transformação da filosofia pré-socrática, por um lado, e pressupuser uma nova compreensão dos fenómenos humanos e naturais, por outro, ou, dito de outra forma, se a filosofia socrática já for uma filosofia da política, para Strauss a filosofia de Farabi, o verdadeiro platonismo, é uma filosofia da política (homem) e na política (cidade). É no significado da filosofia política como um todo que, segundo Strauss, se poderá desvendar o sentido último da perfeição e felicidade humanas na obra de Farabi, bem como compreender o genuíno ensinamento do seu grande predecessor - Platão.

Palavras-chave: Al-Farabi, Leo Strauss, Platão, Aristóteles, Heidegger, pré-socráticos, paganismo, heretismo, filosofia política, ciência política, política, esoterismo, justiça, felicidade, perfeição, virtude.

Abstract: This essay intends to shed light on the question of the true nature of Al-Farabi's political philosophy. To this end - and after a brief introduction about the state of art -, we sought to understand Leo Strauss's controversial and powerful thesis - the great contemporary forerunner of Farabi's studies. We 
sought to demonstrate that for Strauss Farabi was essentially a Platonist; nay, a true Platonist: that who understood, preserved and reproduced the true nature of Platonic philosophy. According to Strauss, Farabi is a true Platonist by endowing, like Plato, his philosophy with a very peculiar form: a political form. The political form is thus the first meaning of Farabi's philosophy, the most immediate, but not its ultimate meaning. Hence, Farabi understood the political form of philosophy as a process of self-knowledge that befalls on Socratic philosophy. If Socratic philosophy is already a transformation of pre-Socratic philosophy, on one hand, and if it presupposes a new understanding of natural and human phenomena, on the other, or, in other words, if Socratic philosophy is already a philosophy about or of the political, for Strauss, Farabi's philosophy, true Platonism, is a philosophy of the political (man) and in the political (city). It is in the meaning of political philosophy as a whole that, according to Strauss, one can not only unveil the ultimate meaning of human perfection and happiness in Farabi's work, but also to understand the genuine teaching of his great predecessor - Plato.

Keywords: Al-Farabi, Leo Strauss, Plato, Aristotle, Heidegger, pre-Socratics, Pagans, Heretics, Political Philosophy, Political Science, Political, Esoterism, Justice, Happiness, Perfection, Virtue.

\section{Introdução}

Após um quase infindável período de intermitência, Al-Farabi (870-950) é hoje amplamente reconhecido como o fundador da filosofia política no mundo islâmico. ${ }^{1} \mathrm{E}$ indiscutível que o rastilho que gerou a actual curiosidade académica por este "grande autor" foi acendido pelo incisivo e controverso estudo académico de Leo Strauss (1899-1973). Os estudantes de Al-Farabi que estão familiarizados com esse estudo podem facilmente argumentar que foi a mera curiosidade histórica que aproximou Strauss de Farabi. Na verdade, porém, foi também a procura da verdadeira história da filosofia política: para Strauss é irónico, mas não de todo acidental, que seja hoje necessário estudar os filósofos islâmicos e judaicos, no contexto da história da filosofia política, tornando assim possível a descoberta do verdadeiro significado da filosofia dos pagãos, i.e., dos "antigos". Por contraposição à filosofia e ciência modernas que conhecem em Heidegger a sua avassaladora crítica, Strauss entende ter descoberto toda uma diferente tradição filosófica, por sua vez olvidada pelo aristotelianismo e neoplatonismo medieval cristão, que escapará à crítica Heideggeriana.

1 "Introduction, 1962 Edition" em Al Farabi, Philosophy of Plato and Aristotle, trans. Muhsin Mahdi, Cornell University Press, Ithaca, 2001, p. 3 - esta será a edição de referência neste trabalho. Veja-se, também, Fauzi Najjar "Farabi's Political Philosophy and shi'ism”, Studia Islamica, No. 14, 1961, p. 57. 
Essa tradição - para qual Strauss reivindica o título de verdadeiro platonismo -, teria sido preservada por figuras tão improváveis como Farabi, Maimónides, Halevi, Lessing, entre outros. La querelle des anciens et des modernes adquire assim o seu pleno significado para Strauss na descontinuidade científica fundamental da tradição filosófica do Ocidente. Ao demonstrar que Platão é o originador de uma tradição filosófica que se eclipsou, primeiro, com o domínio da teologia medieval cristã e, segundo, com a crítica feita pela filosofia e ciência modernas à teologia medieval e à filosofia clássica, a tese do autor de Sein und Zeit de que a "história" do Ocidente corresponde à sua história "metafísica" estaria assim apenas parcialmente correcta.

De um modo geral, poderá ser dito que o Farabi de Strauss procurou fazer com a filosofia, no seu tempo, o mesmo que Strauss procuraria fazer dez séculos mais tarde, viz., recuperar ou "restabelecer" a filosofia quando esta "se torna extinta ou confusa". ${ }^{2}$ Segundo Farabi, a forma de recuperar a filosofia foi transmitida pelos próprios filósofos clássicos. ${ }^{3}$ Neste sentido, seria correcto afirmar que tanto o Farabi de Strauss como o próprio Strauss se preocuparam em recuperar aquele que seria o "sentido original" ou a "verdadeira filosofia" dos filósofos clássicos.

Debruçados sobre a tese de Strauss de que Farabi seria afinal um verdadeiro "platonista", Charles Butterworth e Thomas Pangle procuram explicar porque é que essa tese nunca foi antes claramente evidenciada. No seu entender, a tradição platónica continuada por Farabi foi tão bem-sucedida no mundo islâmico - como comprovarão os nomes Avicena (980-1037), Averróis (1126-1198), etc. - que terá servido de "inspiração" ao aristotelianismo medieval do mundo cristão. Para reconciliar Farabi com a Bíblia, a teologia cristã terá transformado a (verdadeira) filosofia de Farabi - tal como já antes havia acontecido com a filosofia de Platão sob a orientação determinante de Santo Agostinho (354-430) e como voltaria a acontecer mais tarde com a filosofia de Aristóteles sob o impulso mediador de São Tomás de Aquino (1225-1274). ${ }^{4}$ Ao nível político e religioso, por seu turno, o sucesso de Farabi desencadearia toda uma reacção do Islão contra os "filósofos" (falasifa), que, sob a liderança do jurista Al Ghazali ${ }^{5}$ (1058-1111), culminaria na sua "perseguição e erradicação". ${ }^{6}$

\footnotetext{
${ }^{2}$ Al Farabi, Philosophy of Plato and Aristotle, op. cit., p. 50.

3 Ibid., pp. 49-50.

4 Ibid., "Foreword", p. vii.

${ }^{5}$ Considere-se, principalmente, a sua obra The Incoherence of the Philosophers, trans. Micheal Marmura, Provo, Utah, 1997.

${ }^{6}$ Sobre este assunto veja-se Ernest Renan, “Averroès et l'Averroisme, Essai historique", Oeuvres complètes de Ernest Renan, vol.3, Paris, 1949. Ao contrário daquilo
} 
Com a erradicação da filosofia do mundo islâmico, a filosofia islâmica e, em especial, a filosofia de Farabi, ficariam assim reféns do cânone cristão por vários séculos.

Nove séculos após erradicação dos falasifa, foi a vez de Strauss voltar a procurar resgatar o sentido original da filosofia política clássica através de um incisivo estudo da filosofia de Farabi. Esta tarefa monumental pressupôs, antes de mais e por contraposição à interpretação dominante, a clarificação da "verdadeira filosofia" de Farabi através de cinco textos fundamentais, viz., Philosophie und Gesetz: Beiträge zum Verständnis Maimunis und seiner Vorläufer"; "Persecution and the Art of Writing"8; "Quelques remarques sur la science politique de Maïmonide et de Farabi"9; "Farabi's Plato"10 e "How Farabi Reads Plato's Laws"11.

Depois do grande incentivo académico prestado por Strauss as traduções das obras de Farabi multiplicaram-se em poucas décadas. De momento, a língua inglesa já conta com traduções das suas principais obras: A Filosofia de Platão e Aristóteles ${ }^{12}$, que contém três livros - O Alcançar da Felicidade, A Filosofia de Platão e A Filosofia de Aristóteles -; Os Escritos Politicos ${ }^{13}$, a qual inclui quatro livros - Aforismos Seleccionados; Enumeração das Ciências, Livro da Religião; A Harmonização das Opiniões dos Dois Sábios: Platão o Divino e Aristóteles -; e finalmente Sobre o Estado Perfeito. ${ }^{14} \mathrm{O}$ mesmo poderá ser dito, no entanto, sobre as traduções para a língua castelhana, francesa e, em alguma medida, alemã. ${ }^{15}$

A tradução das obras de Farabi da língua árabe para as mais diversas línguas europeias fez-se acompanhar, como se disse, do seu não menos

que se poderia esperar, porém, Strauss sustenta que o carácter "marginal" da filosofia platónica no mundo islâmico assegurou, de certo modo, que o seu carácter genuíno fosse preservado. Sobre este assunto veja-se Strauss, Persecution and the Art of Writing, Glencoe, Ill., The Free Press, 1952, p. 8 e ss. Observe-se o contraste gritante entre a sociologia do conhecimento e a filosofia de Farabi ou verdadeiro platonismo e a sua importância na redefinição da "sociologia da filosofia".

${ }^{7}$ Berlin, Schocken Verlag, 1935.

8 Glencoe, Ill., The Free Press, 1952.

${ }^{9}$ Revue des Etudes Juives, 100, 1936, pp. 1-37.

${ }^{10}$ Louis Ginzberg Jubilee Volume, New York, American Academy for Jewish Research, 1945, pp. 357-393.

${ }^{11}$ Em What is Political Philosophy? And Other Studies, the University of Chicago Press, Chicago, 1988, pp. 134-154.

12 Op. cit.

13 Trad. Charles Butterworth, Cornell University Press, Ithaca, 2001.

14 Trad. Richard Walzer, Oxford University Press, Oxford, 1985.

15 Considere-se as traduções para a língua castelhana de Rafael Ramón Guerrero; para a língua francesa de Dyala Hamzah. 
relevante esforço de interpretação filosófica. Para um grande autor da história da filosofia consideravelmente habituado à penumbra, o séc. XX só lhe havia reservado refulgência. Com o debate filosófico reacendido cedo se tomaram posições hermenêuticas distintas e antagónicas. Em jeito introdutório, poderá ser dito que as posições hermenêuticas da obra de Farabi agruparam-se em função de quatro teses essencialmente distintas: (I) Farabi é essencialmente aristotélico; (II) Farabi é essencialmente platónico; (III) Farabi é platónico e aristotélico; (IV) Farabi é muçulmano. Como já começamos a perceber, Strauss defende nos seus textos e, especialmente, em "Farabi's Plato", contra a opinião geral e num tom caracteristicamente controverso, que Farabi é um verdadeiro platonista. Não será possível recuperarmos aqui a totalidade do debate académico que gravita em torno da questão da correcta interpretação da filosofia de Farabi, por essa razão, limitar-nos-emos a procurar enunciar qual será de certo modo o problema fundamental que o tem vindo a empolar.

De um modo geral, não será difícil observar que Farabi está assaz preocupado em apresentar a filosofia dos "antigos" e, ao mesmo tempo, em enunciar o problema filosófico que é levantado pela "revelação divina". ${ }^{16}$ Por outro lado, também será fácil constatar que o tema da ciência ou arte política é um tema transversal à sua obra. ${ }^{17}$ Estas preocupações pressupuseram de um modo que não é imediatamente claro o argumento de que a filosofia de Platão e de Aristóteles é, não só idêntica no seu "propósito", mas também "uma e mesma filosofia. ${ }^{18} \mathrm{O}$ problema fundamental de que falávamos começa a adquirir uma silhueta ao perguntamos qual seria a razão de Farabi em procurar harmonizar a "filosofia dos "antigos" e em confronta-la com a "revelação divina", por um lado, e, por outro, qual é a relevância desta tese para a ciência ou arte política? Poderemos falar de uma hierarquia das suas obras ou, pelo menos, da possibilidade de que uma das suas obras espelhe a sua intenção global e por isso forneça a chave interpretativa? Não poderá ser dito que Farabi estaria unicamente interessado em reconciliar os requerimentos da fé islâmica com a filosofia dos antigos, à luz de um contexto político fortemente marcado pela Shari'a?

Uma das respostas frequentemente dadas a estas questões é, como observa Muhsin Mahdi (1926-2007) - um dos académicos que liderou as investigações e traduções da obra de Farabi -, a de que a filosofia islâmica, da qual Farabi foi parte preponderante, constitui "uma mistura, combinação ou síntese de doutrinas aristotélicas, platónicas, neoplatóni-

\footnotetext{
${ }^{16}$ Al Farabi, Harmonization, §1, §81; Enumeration, §5.

17 Al Farabi, Selected Aphorism, §3, §4, §5; Book of Religion, §1; Enumeration, §1, $\S 2, \S 3$ - observe-se, também, o título On the Perfect State.

18 Al Farabi, Attainment, §64.
} 
cas e, é claro, islâmicas". ${ }^{19}$ Neste sentido, esta resposta sugere a ideia de que os filósofos islâmicos teriam "pouca percepção" de que combinariam doutrinas, por vezes muito, nas outras tantas vezes pouco ou nada harmonizáveis. Na larga maioria das vezes, esses "filósofos" decidiriam o conflito entre essas doutrinas a "favor da sua fé religiosa" - como parecem indicar, deveremos acrescentar, muitos comentadores do estudo de Averróis sobre a República de Platão. ${ }^{20}$ Farabi procuraria reconciliar Aristóteles com Platão, "o divino", i.e., com um Platão certamente mais neoplatónico e inspirado na Teologia de Aristóteles de Plotino, de modo a assegurar que Aristóteles está ao contrário do que se julga em perfeita sintonia com Platão na adopção de doutrinas incontestáveis no mundo islâmico, viz., a imortalidade da alma, a criação do mundo, as punições divinas após a morte, etc.

Embora seja perceptível que possa subscrever a tese de que Farabi procuraria afastar o rótulo de heterodoxia religiosa cultivando a ideia de uma suposta "harmonização", Strauss opõe-se categoricamente à ideia de que Farabi acreditava genuinamente nela. Dito de outra forma, sublinha o facto de Farabi ter a perfeita noção do carácter necessariamente "herético" da filosofia dos "pagãos" - coisa que para Strauss se tornará especialmente manifesta na Filosofia de Platão. Por outro lado, nega que Farabi seja aristotélico em razão de Aristóteles carecer de uma filosofia política, ou seja, de carecer entre outras coisas de um tratamento político da filosofia. ${ }^{21}$ A diferença entre Platão e Aristóteles seria uma diferença quanto à forma, não quanto à substância, mas essa diferença na forma altera a própria substância das suas filosofias. ${ }^{22} \mathrm{~A}$ forma platónica ou o tratamento político da filosofia seriam o resultado do conhecimento filosófico das coisas políticas ou, dito de outra forma, da percepção de que existe uma tensão fundamental entre a filosofia e qualquer comunidade

19 "Introduction, 1962 Edition" em Al Farabi, Philosophy of Plato and Aristotle, op. cit., p. 3.

20 Sobre este assunto veja-se "Introduction", p. xv e ss. em Averroes, On Plato's Republic, trans. Ralph Lerner, Cornell University Press, Ithaca, 1974.

${ }^{21}$ Compare-se Strauss, "Farabi's Plato", p. 359 (a maneira de apresentar a filosofia) com p. 371 (Aristóteles não estava sob "compulsão") e com What is Political Philosophy?, University of Chicago Press, Chicago, 1988, p. 93. Compare-se ainda Al Farabi, Attainment, § 64, com Aristotle, §1 e com Harmonization, §12, §13, §14, §15 e §16. Farabi diz-nos que a sua filosofia é a mesma no "propósito" e que a sua filosofia é "uma e a mesma", mas também nos diz que o procedimento de Aristóteles difere daquele próprio de Platão, na procura que aquele cultiva por uma maior clarificação. Esta ideia reflectir-se-ia por sua vez na arte escrita de ambos os autores.

22 Strauss, Thoughts on Maquiavelli, The University of Chicago Press, Chicago \& London, 1978, p. 59. 
política - ideia esta que não será tão evidente na obra de Aristóteles porque este terá fundado, ao contrário de Platão, uma ciência política quase totalmente isolada da filosofia.

Alguns autores, como Paul Walker, criticam fortemente Strauss por este depender do binómio esoterismo/exoterismo na interpretação da filosofia de Farabi, binómio esse que não pode ser provado. ${ }^{23}$ Admitindo que não pode ser provado, Walker é levado a negar a existência de uma tensão natural entre a filosofia e a comunidade política e, por conseguinte, a insistir na concordância entre o Platão e o Aristóteles de Farabi. ${ }^{24}$ Para sustentar a sua tese Walter não desenvolve, contudo, uma análise e crítica da ideia de uma suposta tensão fundamental entre a filosofia e a comunidade política, mas limita-se a apresentar uma outra possibilidade interpretativa que, não obstante, merecerá certamente toda a atenção do estudante, viz., a de que Farabi não recorria a uma escrita esotérica, mas apenas a uma escrita "popular". Por conseguinte, a sua crítica não atinge verdadeiramente o "nervo" do argumento de Strauss, coisa que poderá ser ilustrada pela seguinte passagem do artigo de Walker: "na verdade, nenhuma harmonização é requerida. A filosofia dos três [Platão, Aristóteles e Farabi] é a mesma, pelo menos no seu propósito e intenção". ${ }^{25}$

A maior dificuldade que Strauss enfrenta não é - como diz Walker - a de uma falta de provas, mas antes a impressão de que o próprio Farabi critica de algum modo a "revelação divina" e os seus modos derivados de intelecção (takhyil) e de discurso (kalãm) naquelas mesmas obras que Strauss considera "exotéricas", i.e., destinadas a apresentar visões mais ou menos ortodoxas. ${ }^{26}$

Seja como for, o estudo de Strauss não poderá ser menosprezado por nenhum académico que hoje vise compreender a filosofia de Farabi. O seu estudo impõe-se como uma referência incontornável no tempo e no contexto da história da filosofia política, seja pela força da sua tese ou consistência do seu argumento, seja pela abordagem interpretativa que favorece, seja ainda por retirar parte do seu pendor da totalidade da

\footnotetext{
23 "Platonism in Islamic Philosophy", Studia Islamica, No. 79, 1994, p. 12 e ss.

24 Ibid., pp. 16-17.

${ }^{25}$ Ibid., p. 17.

${ }^{26}$ Considere-se, só para dar alguns exemplos, Selected Aphorism, §75 e §76: onde Farabi nega explicitamente, primeiro, que a inveja e a ganância sejam necessariamente males - o que também não quererá dizer que sejam bens - e, segundo, que a felicidade não é uma forma de recompensa pelas boas acções. Considere-se ainda a evidente depreciação da religião face à filosofia, realizada em Attainment, $§ 52, \S 53 \S 54$ e sobretudo, $\S 55$, a partir da qual se poderá concluir, no contexto dos aforismos anteriores, que a religião não constitui nem a perfeição, nem a felicidade mais elevadas do homem.
} 
obra de Strauss: o académico que vise apresentar uma interpretação da filosofia de Farabi que reclame rigor científico, fará muito, senão (quase) tudo, ao passar pelo herculeano desafio de refutar Strauss. Neste trabalho não procuraremos senão desenvolver uma introdução crítica do dialéctico "Farabi's Plato" de Strauss, i.e., aquele que deve ser o ponto de partida para compreender o Farabi de Strauss, clarificar o seu intricadíssimo argumento e a sua quase imperceptível tese fundamental.

\section{A separação da filosofia ou arte de Timeu da ciência política}

Strauss parece seguir Farabi ao reconhecer que a ciência ou arte política, da qual o tema de fundo é a "perfeição do homem ou a felicidade"27, compõe apenas parte da investigação platónica. A outra parte da investigação platónica é fornecida pela filosofia "propriamente dita". ${ }^{28}$ A opinião comum segundo a qual a filosofia de Platão e a filosofia de Farabi têm um "significado político" ("Farabi's Plato", 362) estaria assim, para Strauss, incompleta. Estaria completa se o assunto por excelência da filosofia fosse a "felicidade" ou as "coisas políticas" ou Humanas, mas como o Farabi de Strauss procuraria demonstrar, a ciência política e a filosofia são duas ciências ou artes com objectos de estudo essencialmente diferentes, muito embora estabeleçam uma decisiva relação entre si. É a definição do carácter ou natureza destas duas ciências, assim como o estudo da sua relação, que ocupa parte da atenção de Strauss no seu "Farabi's Plato".

De acordo com o Farabi de Strauss, a ciência política "fornece" a ciência do "modo de vida desejável"29, i.e., é uma ciência ou arte que de certo modo investiga qual é o melhor modo de vida ou o modo de vida "correcto" dentre do conjunto de todos os modos de vida e serve-se desse conhecimento para governar. Neste sentido, ao se dizer que a arte ou ciência política se debruça sobre as "coisas políticas" ou sobre as "coisas nobres" e "justas", o Farabi de Strauss não estaria senão a dizer que a questão política fundamental é a questão do melhor modo de vida e que esta questão precede a própria questão da justiça, nobreza e melhor regime político. ${ }^{30}$ Outra forma de dizer que a ciência ou a arte política se debruça sobre a questão do melhor modo de vida será dizer que o tema último da ciência política é a "felicidade": o melhor modo de vida é o modo de vida mais feliz ou o único modo de vida que "verdadeiramente

${ }^{27}$ Al Farabi, Enumeration, §1.

28 Al Farabi, Plato, $\$ 3$ e $\S 4$.

${ }^{29}$ Al Farabi, ibid., §21.

30 Só respondendo à pergunta "como deve o homem viver?" é que o homem poderia responder satisfatoriamente à questão "qual é o melhor regime político?", i.e., o regime onde o homem poderá ter o melhor modo de vida ou ser feliz. 
é feliz". Como observa Christopher Colmo, a investigação do melhor regime político pressupõe, em Farabi, a investigação do melhor modo de vida ou da felicidade. ${ }^{31}$ A ciência ou arte política, própria do governante ou do político, pressupõe o conhecimento da felicidade.

Strauss acrescenta, no entanto, que o Platão de Farabi também discute "o carácter essencial da filosofia" no "contexto" da discussão da ciência política, ou seja, discute outra coisa que não é a ciência política, viz., a filosofia, no contexto da discussão sobre os "assuntos políticos" (363) este seria o significado algo impreciso do diálogo platónico. Em todo o diálogo platónico, mesmo naquele em que os "assuntos políticos" não adquirem proeminência, por detrás da investigação filosófica propriamente dita residiria a questão política fundamental. Contudo, uma coisa é dizer que todo o diálogo platónico incorpora duas questões, a saber, a questão política e a questão filosófica, outra coisa inteiramente diferente será dizer que a ciência política aponta para a filosofia, i.e., que a questão política aponta necessariamente para a questão filosófica, mesmo que esta nunca venha a ser descoberta: se a ciência política fornecer, entre outras coisas, a ciência sobre o melhor modo de vida ou sobre a felicidade, torna-se fundamental ao bom desempenho da arte ou ciência política levantar a questão teórica o que é (tis estin) a felicidade (eudaimonia)? Ou 'o que é a virtude (aretê)? Outra forma de formular este problema será perguntar quais são as artes ou as ciências que o homem precisará de possuir "para se alcançar a felicidade que lhe dá a sua perfeição [autotéleia] ultima"? ${ }^{32}$ Este seria o primeiro significado da filosofia, i.e., o de filosofia enquanto investigação política, ou melhor, o de uma interrogação tipicamente política acerca de uma assunto especificamente humano ou político que se procura naturalmente corresponder com a filosofia.

A ciência política não se corresponde com a filosofia senão na sua relação com a felicidade, ou seja, senão na sua importância para responder à questão política do melhor modo de vida. ${ }^{33}$ Como veremos mais adiante, para Strauss, este é de algum modo o significado da filosofia moral de Sócrates e não o estrito significado da filosofia de Platão. Seja como for, Strauss faz desde logo por realçar que para Farabi a investigação política da filosofia "não esgota" o significado da filosofia "propriamente dita" (363); ela limita o objecto da sua investigação à relação entre a investigação da felicidade e as "coisas políticas". Ela faz uma solicitação à

31 "Theory and Practice: Alfarabi's Plato Revisited", The American Political Science Review, Vol. 86, No. 4, 1992, p. 966. Sobre a relação entre a ciência política e a felicidade, veja-se também Strauss, "Some Remarks on the Political Science of Maimonides and Al Farabi”, pp. 9-10; Al Farabi, Selected Aphorism, §25, §30, etc.; Enumeration, §1.

${ }^{32}$ Al Farabi, Plato, $\S 1$.

33 Veja-se, por exemplo, Al Farabi, Selected Aphorisms, §5. 
filosofia ao perguntar "qual é o melhor modo de vida?", mas o significado último da filosofia e, por outro lado, a resposta última a esta questão, não só iludem a ciência ou arte política, como pertencem ao domínio da investigação filosófica propriamente dita (363-364). Resumindo, para o Farabi de Strauss a ciência política é pré-filosófica.

Aqui surge um problema: a ciência política é forçada a perguntar o que é a felicidade ou qual é o melhor modo de vida, mas para o Farabi de Strauss as "coisas políticas", no geral, não são nem "o único tema" (363), nem o "principal tema"(364), nem a maior parte do conjunto dos temas da filosofia. "Na verdade", esclarece Strauss, o Platão de Farabi "exclui os temas políticos e morais da filosofia propriamente dita". Com esta linha de argumentação, Strauss está no fundo a enfatizar o facto de que o a questão levantada pela ciência política permanece num limbo: ela é suscitada pela ciência política, que por sua vez solicita o auxílio da filosofia, mas esta não se pronuncia sobre esse tipo de questões. Fica subentendido por conseguinte que para o Farabi de Strauss a filosofia, ao excluir as "coisas políticas da sua investigação", não se pronuncia sobre as questões humanas ou sobre questão política fundamental. ${ }^{34}$

Teremos de indagar porque é que para o Farabi de Strauss a filosofia exclui os "assuntos políticos" da sua investigação. Strauss é fiel a Farabi ao observar que este opera uma "distinção fundamental" entre o "modo de vida" e a "ciência" "indispensáveis à felicidade" (364). ${ }^{35}$ A ciência política pronunciar-se-ia sobre a questão do "modo de vida" e, por outro lado, a filosofia pronunciar-se-ia sobre a questão da "ciência". ${ }^{36}$ A filosofia ou arte de Timeu debruçar-se-ia sobre os "seres naturais e divinos"; já a ciência política debruçar-se-ia sobre a questão do "modo de vida". Esta distinção tornar-se-ia fundamental em razão de apenas os "seres naturais e divinos", i.e., aquelas coisas que verdadeiramente são, poderem ser objectos de "demonstração" 37 ; ao passo que os "modos de vida", não sendo "seres", mas sendo "coisas", tal como a felicidade e a perfeição, não podem ser filosoficamente demonstrados e por conseguinte deslizam para fora da investigação filosófica (compare-se 364-365 com 389-390). ${ }^{38}$

${ }^{34}$ Se o Farabi de Strauss parasse aqui, Christopher Colmo estaria perfeitamente justificado em afirmar que "Strauss answers the question clearly by affirming that the knowledge of the best way of life is itself practical, not theoretical, knowledge. I give reasons why this position is not persuasive". - "Theory and Practice: Alfarabi's Plato Revisited", the American Political Science Review, Vol. 86, No. 4, 1992, p. 967.

${ }^{35}$ Al Farabi, Plato, \$3.

36 Ibid., §19, §20, §21.

${ }^{37}$ Al Farabi, Attainment, $\$ 46 ; 50$, etc.

${ }^{38}$ Realmente em Plato, $§ 10$, Farabi insinua que o conhecimento dos seres é diferente do conhecimento do modo de vida. 
A filosofia é a arte teórica que fornece a ciência da "substância de cada um dos seres" e, enquanto tal, não se pronuncia sobre aquelas "coisas" que não são simultaneamente "coisas" e "seres", pois, "todos os seres são coisas", mas nem todas as coisas são seres. Como parece ser verdade que Farabi omite do seu sumário da filosofia de Platão qualquer referência às "ideias de justiça e de outras virtudes", Strauss reforça o seu argumento de que as "coisas políticas", os objectos de estudo da ciência política, não são entendidos como "seres". 39

\section{A reconciliação da filosofia ou arte de Timeu com a ciência política: a caminho da arte de Sócrates}

Tendo distinguido estas duas ciências, Strauss procede à análise da sua "reconciliação" (365 e ss.). Podemos ser tentados a argumentar contra Strauss que a ciência política, ao conduzir para lá do seu objecto de estudo em direcção à filosofia, acaba eventualmente por ser abandonada por esta, mas Strauss responde implicitamente a esta objecção ao afirmar que "o filósofo que, transcendendo a esfera das coisas morais e políticas, se ocupa da procura pela essência de todos os seres, tem de dar uma justificação da suas acções respondendo à questão 'porquê a filosofia?'. Essa questão não pode ser respondida senão tendo em vista o fim do homem, o qual será a felicidade, e, na medida em que o homem é por natureza um ser político, não pode ser respondida senão dentro de um quadro-de-referência político. Por outras palavras, a questão 'porquê a filosofia?' é apenas uma 'forma especial' da questão 'qual é o modo de vida correcto?', i.e., da questão que guia todas as investigações morais e políticas" (365-336). Nesta passagem, Strauss parece evidenciar dois problemas distintos, mas igualmente fundamentais. O primeiro será o de que o filósofo qua filósofo "tem" de justificar a sua actividade. O segundo será o de que a justificação da sua actividade não pode ser feita senão à luz do fim (telos/hadaf) do homem e do facto de o homem ser por natureza um animal político.

Comecemos pelo primeiro problema, pelo problema do rigor filosófico. Porque é que o filósofo "tem" de justificar a sua actividade? $\mathrm{O}$ "tem" designará um dever, uma necessidade ou uma condição? Strauss parece fundamentar o "tem" na ideia de que, toda a sophia que não se faça acompanhar de sophrosyne não é genuinamente sophia, baseando-se numa leitura muito peculiar do enigmático vigésimo segundo parágrafo da Filosofia de Platão (compare-se 366 com 367 e ss.). Neste sentido, o filósofo não pode ser um filósofo sem se debruçar também sobre os

${ }^{39}$ Veja-se, por exemplo, o sumário de Farabi sobre o Fédon e sobre a República em, Plato, $\S 30, \S 31$. 
assuntos da ciência política - uma das condições indispensáveis ao rigor da filosofia é a própria ciência política, na medida em que a filosofia não investiga as coisas humanas ou políticas - "sophia e sophrosune (...) não podem ser separadas uma da outra". O filósofo que desenvolve uma investigação filosófica sem procurar justificar a sua actividade assemelha-se, como veremos, ao "homem moral" (compare-se 366 com 389). O segundo problema depende do primeiro - a necessidade de uma justificação da filosofia resulta da necessidade de sophrosune do filósofo. Recuperemos, antes de mais, a parte da passagem anteriormente transcrita que nos interessa: a pergunta "porquê a filosofia?" "não pode ser respondida senão tendo em vista o fim do homem, o qual será a felicidade, e, na medida em que o homem é por natureza um ser político, não pode ser respondida senão dentro de um quadro-de-referência político". Como é possível observar, Strauss não identifica completamente o fim do homem, a felicidade, com a natureza política do homem ou com aquilo a que Farabi apelida de "primeira perfeição" - o que vale por dizer que a filosofia, i.e., a segunda perfeição ou a "perfeição mais elevada e final" do homem, também constitui um fim humano. O mesmo será dizer, a justificação da filosofia ou a resposta à questão política fundamental não se esgota na natureza política do homem, mas está-lhe sobreposta. ${ }^{40} \mathrm{Na}$ medida em que o homem é "por natureza um animal político", toda a justificação da filosofia é também necessariamente uma justificação política. É apenas em razão de a filosofia não se pronunciar sobre as coisas humanas e políticas que a justificação da filosofia fica, por demérito da própria filosofia, entregue à ciência política.

Antes de continuarmos a procurar acompanhar o argumento de Strauss sobre a reconciliação, impõe-se-nos perguntar porque é que, na sua opinião, poderá ser dito que para Farabi o homem moral assemelha-se ao homem puramente teórico ou ao filósofo que não se debruça sobre a ciência política? Em que medida é que eles são idênticos? Strauss diz-nos que para Farabi a diferença entre o "modo de vida verdadeiramente virtuoso" e "todos os outros modos de vida" é baseada, não "numa diferença de propósito ou de qualidade da vontade", mas "numa diferença de conhecimento" (389). Já a diferença entre uma "escolha moral" e uma "escolha que não é moral" consiste numa "diferença de propósito" e não numa "diferença de conhecimento" (388). Dito isto, torna-se curioso que o próprio Strauss diga que "existe um acordo alargado entre a conduta do homem moral e a do filósofo: esse acordo permitiria aplicar um mesmo

40 Strauss parece fundamentar a ideia de que o homem é um ser político na ideia de que o fim do homem é a felicidade, i.e., um assunto próprio da ciência ou arte política. Sobre este assunto veja-se Averroes, On Plato's Republic, 22, 9-29. 
termo ('virtude') a ambos" (389). Ora, se um homem moral tem virtude porque se submete às "exigências da honra e do dever sem questionar porquê", ou seja, porque faz o que é correcto sem questionar o que é correcto (ao contrário de Sócrates), estamos habilitados a concluir que, para Strauss, o filósofo, i.e., aquele que se limita ao estudo da "substância de cada um dos seres", também levará a cabo a sua investigação, pelo menos na estrita qualidade de filósofo, sem questionar a razão pela qual a faz enquanto homem - a virtude teórica assemelhar-se-ia à virtude prática na medida em que ambas são um 'fazer o que é correcto (sem indagar porquê)', i.e., fazer o que é correcto à luz da perfeição ou natureza a que se reportam. O homem moral tem virtude de algum modo por falta de sophia; o filósofo qua filósofo tem virtude mesmo que de algum modo careça de sophrosune. Ambos estão correctos de forma incompleta porque apenas se reportam a uma das duas perfeições - o homem moral à perfeição política e o filósofo à perfeição teorética. Observe-se que Strauss diz que aquilo que assemelha o filósofo ao homem moral é a virtude ou o fazer aquilo que é correcto e não a moral per se. O filósofo qua filósofo não é um homem moral, i.e., aquilo que é correcto para o homem moral e à luz da natureza política do homem (justiça, nobreza, etc.), difere daquilo que é correcto para o filósofo ou da natureza teorética do homem (o acto de conhecer ou contemplar). Isto também nos permite concluir que, nem o homem moral, nem o mero filósofo, corresponderão àquele que leva "o modo de vida verdadeiramente virtuoso", i.e., ao homem simplesmente perfeito. O filósofo qua filósofo ou Timeu não é necessariamente prejudicial para o homem moral, ao contrário de Sócrates, porque Timeu não pergunta 'o que é a virtude?', ou seja, porque ele não investiga as coisas humanas. Seja como for, poderá ser dito que esta linha de argumentação representa a crítica do Farabi de Strauss a Timeu (ou aos pré-socráticos) e, por outro lado, ao mero homem moral.

Retomando a discussão da "reconciliação", Strauss separa, respeitando o seu Farabi, a ciência política e os seus objectos de estudo, por um lado, da filosofia e dos seus objectos de estudo, por outro. De seguida, diz-nos que a ciência política pressupõe a filosofia e, por outro lado, que a filosofia não consegue desprender-se inteiramente da ciência política em razão de o homem ser um "animal político". A ciência política complementa a filosofia e vice-versa, ou seja, para além da investigação filosófica sobre os seres, o filósofo é forçado a desenvolver uma investigação não-filosófica das coisas que não são seres, i.e., das coisas políticas. Ainda que o filósofo (ou o político que procure conhecer o que é a felicidade) tenha de executar duas investigações essencialmente distintas, Strauss enfatiza o facto de que as duas não pertencem ao "mesmo nível": a filosofia propriamente dita, estudando os "seres" e sendo uma arte "demonstrativa", é 
enquanto tal superior à ciência política - que para todos os efeitos retém um carácter essencialmente prático. Seria por esta razão que, segundo ele, Farabi renunciaria à diferenciação "filosofia prática"/"filosofia teórica" no seu sumário sobre a filosofia de Platão, ao contrário do que acontece por exemplo no Alcançar da Felicidade e em outras obras suas. O mesmo vale por dizer, a filosofia é por definição "teórica", o que a tornará superior. Argumentaremos que Strauss sublinha, num primeiro momento, a superioridade da filosofia face à ciência política para que possa assinalar num segundo momento a superioridade da filosofia enquanto ciência de "todas as coisas" face à filosofia enquanto ciência da substância de cada um dos seres.

\section{A filosofia política ou a arte de Sócrates ${ }^{41}$}

No ensaio de Strauss, existe um contraste muito discreto entre a mera ciência ou arte política, por um lado, e a ciência política "na sua forma final", a "verdadeira arte real", a "arte de Sócrates" ou a "filosofia política", por outro (compare-se, por exemplo, 363 com 367 e 389-390). Como Strauss não faz deste segundo tipo de ciência política um tema explícito no seu próprio ensaio será extremamente fácil e tentador perder de vista a necessidade de procurar pela distinção fundamental entre as duas - Strauss só emprega o termo "filosofia política" uma vez, o "seu Farabi’s Plato" parece ser um mero tratado de filosofia.

A distinção entre filosofia política e ciência política não é estranha para Farabi, embora não a faça explicitamente na Filosofia de Platão. $\mathrm{Na}$ Enumeração das Ciências, Farabi distingue a filosofia política da ciência política. ${ }^{42}$ Apresenta a ciência política como uma ciência que é composta por duas faculdades. Uma é a faculdade "para regras universais", a outra é a "experiência". A filosofia política, por seu lado, está "limitada" às regras universais. Strauss parece seguir Farabi ao afirmar que a diferença entre a filosofia política e a ciência política reflectir-se-ia no facto de o Sócrates (de Platão) não se pronunciar sobre as leis, sobre as coisas práticas ou sobre os assuntos práticos da ciência política, mesmo quando o diálogo das Leis lhe é "atribuído", i.e., um diálogo que discute leis. ${ }^{43}$ Sócrates só investiga as coisas políticas no sentido mais elevado, i.e., as coisas políticas verdadeiramente morais ou a "excelência" (391); ele não investiga

${ }^{41}$ Note-se que a identificação da arte com a ciência, feita pelo Farabi de Strauss e que tentámos preservar aqui, reflecte a ideia de que não existe um método científico de raiz, mas antes a ideia de que só se poderá ter um início não-científico para a actividade teórica, tal como acontecerá com as demais artes ou perícias práticas.

${ }^{42}$ Compare-se a parte 1 com a parte 2 do capítulo 5 .

${ }^{43}$ What is Political Philosophy?, op. cit. p. 153. 
filosoficamente as coisas políticas existentes, mas as coisas humanas que mais verdadeiramente são. ${ }^{44}$

No decorrer da primeira discussão em que é assinalada a necessidade de ciência política no contexto da investigação puramente filosófica (365-366), Strauss alude pela primeira vez à filosofia $d a$ política, i.e., à filosofia que incluiria os "assuntos políticos" na sua investigação. A filosofia política, distinguir-se-ia, no entanto, quer da filosofia propriamente dita, quer da ciência política no sentido original do termo. Esta alusão é, todavia, tão discreta que o leitor poderá facilmente toma-la por um corolário da mera ciência ou arte política. Diz-nos Strauss, "esta questão [porquê a filosofia?] e a sua resposta, as quais são estritamente falando meramente preliminares, podem ser descritas em todo o caso como filosóficas dado que apenas o filósofo é competente para elaborar essa questão e para lhe responder" (366). Dito de outra forma, a resposta à pergunta "porquê a filosofia?" é meramente "preliminar" porque é levantada e respondida, numa primeira instância, somente pela ciência política. Tendo em conta o que já discutimos, a saber, que a ciência política não é idêntica à filosofia, qualquer resposta dada a esta questão não alcança o carácter demonstrativo. Ao fazer desta pergunta uma questão filosófica, o filósofo procuraria transformar uma questão essencialmente prática ou política numa questão essencialmente teórica ou filosófica. O filósofo estaria a "fazer a filosofia descer dos céus" e a "forçá-la" a pronunciar-se sobre os "assuntos políticos" ou "humanos", i.e., sobre assuntos que, ao contrário dos assuntos "naturais ou divinos", carecem de rigor demonstrativo - este é, como veremos, o significado da filosofia de Sócrates para o Farabi de Strauss. ${ }^{45}$ Como é que o Platão de Farabi conseguirá alcançar o efeito pretendido através de uma arte teórica ou filosofia que se confina à investigação da substância de cada um dos seres?

Como já tivemos oportunidade de referir, Strauss vinca o facto de o Platão de Farabi rejeitar implicitamente a possibilidade de "ideias de justiça e de outras virtudes" (364). Esta observação de Strauss dá a entender que a justiça e as outras virtudes não são seres, mas apenas coisas ou, mais concretamente, coisas políticas e humanas. Poder-se-ia dizer, então, que existiria filosofia política se houvesse, não uma investigação de algo como dos seres políticos ou de uma ética metafisicamente fundada, mas da investigação filosófica das "coisas políticas". A arte de Sócrates torna possível a filosofia política porque através da sua "abordagem" ele observa que as «coisas» que não são «seres» são "essencialmente dependentes dos

\footnotetext{
44 Sobre os graus dos seres, veja-se Aphorisms, $§ 68$ e ss.

45 Strauss, Natural Right and History, início do capítulo IV. Sobre a transformação da filosofia na filosofia política veja-se Al Farabi, Aphorisms, §94, §95, §96.
} 
seres". ${ }^{46}$ Por conseguinte, dado que "a compreensão completa da essência" de "todas as coisas" e das suas relações pressupõe "a compreensão da essência de todos os seres", a filosofia pode ser chamada de "ciência da essência das coisas" - dito por outras palavras, esta filosofia abarcaria as coisas que são e não são seres (389-390). Ao falar de compreensão "completa" da essência de todas as coisas, Strauss não nega que a ciência política seja uma ciência das coisas ou que ela não se possa pronunciar sobre todas as coisas, mas nega tacitamente que a investigação política dos assuntos políticos "esgote" a própria análise das "coisas políticas" ou que analise a natureza de todas as coisas à luz da distinção entre "seres" e "coisas". Além disso, insinua também que a "ciência da substância de cada um dos seres" não é idêntica à "ciência da essência das coisas". A arte de Sócrates pressupõe a arte de Timeu ou a distinção entre seres e coisas, mas a arte de Timeu assenta na suposição, ainda por examinar, de que a sua arte não requer a arte política. A felicidade, sendo uma coisa e não um ser, tal como a perfeição, seriam investigadas mais completamente pela filosofia política do que pela mera ciência política, pois, aquela estudaria a felicidade e a perfeição na sua relação com os "seres" e não apenas como "coisas" humanas. ${ }^{47}$ Para levar a cabo a investigação filosófica da felicidade e da perfeição, Sócrates é por princípio obrigado a enfatizar a diferença entre a verdadeira felicidade e a verdadeira perfeição, por um lado, e, por outro, as meras opiniões sobre a felicidade e a perfeição. Dito de outra forma, Sócrates é levado a vincar a diferença entre os modos de vida por todos reconhecidos como detentores de virtude, entre os quais se conta o modo de vida moral, e o modo de vida "que verdadeiramente tem virtude".

A investigação política que se fecha grosso modo à investigação filosófica encontraria um dos seus exemplos mais acabados na Política de Aristóteles. Enquanto tal, Aristóteles escreveria para o homem moral, i.e., para aquele homem que não precisa de examinar o que é a justiça para avaliar se uma certa acção é ou não correcta. ${ }^{48}$ Já a República de Platão seria um dos exemplos mais acabados de uma investigação política que não se fecha à investigação teórica ou filosófica.

Ao converter as coisas políticas num assunto filosófico, a arte de Sócrates torna a questão política maior do "modo de vida correcto" -

46 Quando discute as "ideias", Strauss parece ter sempre em vista Heidegger e as interpretações cristãs da República.

${ }^{47}$ Outra forma de dizer isto será dizer que a filosofia política olha para os fenómenos humanos e políticos do ponto de vista de physis e não meramente de nomos.

48 É por esta razão que Strauss argumenta em "Aristotle's Politics" que a ciência política de Aristóteles difere da ciência política de Platão, na medida em que aquele a separa da "filosofia natural". 
assim como as demais questões humanas (felicidade, perfeição, nobreza, prazer, etc.) -, susceptíveis de vir a obter uma resposta filosófica ou demonstrativa ${ }^{49}$ Dizer que a arte de Sócrates é a filosofia política significa admitir que Sócrates limita o objecto dos seus estudos às "coisas políticas", i.e., Sócrates não estuda os seres senão na sua relação com as coisas políticas ou humanas - Sócrates articula os seres e as coisas humanas para conhecer as coisas humanas mais perfeitamente e não, ao contrário de Platão, para conhecer os seres ou as coisas que mais perfeitamente são.

\section{A verdadeira filosofia: a caminho da arte de Platão}

Como já referimos, Strauss nunca identifica explicitamente a filosofia política ou a arte de Sócrates como um dos seus principais temas; neste sentido, poderá ser dito que ele imita Farabi na medida em que "(...) o leitor fica incumbido de descobrir [o seu significado] através da sua própria reflexão" (369). Será possível observar, no entanto, que ela é parte integrante do seu principal tema assim que Strauss distingue a mera "filosofia de Platão" daquilo que Farabi entende ser a "verdadeira filosofia de Platão". Ao fazer da arte de Sócrates parte integrante da "verdadeira filosofia política", estar-se-ia a admitir que a arte de Sócrates não é simplesmente idêntica à arte de Platão. Como veremos, para o Farabi de Strauss a arte de Platão pressupõe, tanto a arte de Timeu, como a arte de Sócrates. Como estas duas artes não garantem a possibilidade de filosofia e por isso a possibilidade de o homem ser verdadeiramente feliz, a arte de Platão requer ainda, como veremos, a arte de Trasímaco (382-385)..$^{50}$ Para definir a arte de Platão será preciso demonstrar a insuficiência da arte de Sócrates, de Timeu e de Trasímaco, por um lado, e, por outro, explicar qual será a sua respectiva articulação à luz da arte de Platão. Até ao momento já foram analisadas a arte de Timeu e a origem da filosofia política ou arte de Sócrates.

\section{A insuficiência da arte de Sócrates}

Motivado pela "convicção" de que a única vida que merece ser realmente vivida é a vida daquele que indaga qual é o modo de vida e a ciência indispensáveis à felicidade, Sócrates é levado a preferir a morte a

${ }^{49}$ Em What Is Political Philosophy?, op. cit., p. 89, Strauss contesta a possibilidade de a filosofia conseguir demonstrar as distinções "politicamente relevantes", sem que ao mesmo tempo se desemboque em visões verdadeiramente "paradoxais", i.e., que são "contraditórias" e "ridículas" (pp. 90-91).

50 Veja-se ainda What Is Political Philosophy?, op. cit., pp. 152-154. 
uma vida sem filosofia assim que a cidade o confronta com esse ultimato. ${ }^{51}$ Sócrates chega ao ponto de ser julgado pela cidade porque, ao procurar por aquilo que é indispensável à felicidade, é levado a afirmar que não deveremos contentar-nos com as "opiniões" dos nossos "compatriotas" e "ancestrais" sem as fazermos acompanhar da sua diligente análise ou exame. ${ }^{52}$ Como parece ser "muito improvável que [Sócrates] possa alcançar aquilo que quer" nas cidades existentes, pois, "ele será necessariamente visitado" pela "morte ou privação de perfeição", tornara-se evidente para si a necessidade de fundar uma "outra cidade", i.e., uma cidade onde Sócrates pudesse levar a cabo a sua investigação (385-389). ${ }^{53}$

\section{A cidade justa ou perfeita e a origem da arte de Platão.}

Ao necessitar de uma "outra cidade", o Sócrates de Farabi é levado a investigar a "verdadeira justiça" e a distingui-la das erróneas opiniões sobre a justiça. Teremos de perguntar se para Farabi a verdadeira justiça seria favorável à filosofia. Farabi parece reconhecer que sim ao afirmar que - sendo a cidade justa uma cidade onde não faltarão quaisquer bens verdadeiramente bons, o que implica que não "falta nada" daquilo que possa levar os seus cidadãos à felicidade -, torna-se "indispensável" que a "arte do príncipe" seja a "verdadeira filosofia", que os filósofos constituam a sua "parte mais elevada" e que todos os cidadãos da cidade justa sejam seus subordinados. ${ }^{54}$ Como resume Strauss, a cidade justa requer o "exercício actual da arte real pelos filósofos numa comunidade política definida" ou o governo dos filósofos (379). Seja como for, Strauss parece divergir neste ponto de Farabi. Enquanto que Farabi parece restringir o propósito da concepção da cidade justa à garantia de Sócrates poder vir a exercer a sua arte sem perigos, Strauss diz-nos que esta ideia deve ser entendida à luz da possibilidade de todos os homens serem felizes ou, antes, de todo o homem poder ser um filósofo (378-379). Antes de discutirmos este assunto, porém, será necessário compreender que para Farabi a cidade justa existe, primeiro, apenas "em discurso". Ao analisar a questão da possibilidade de a cidade justa existir "em actos", Farabi reconhece que ela depende do legislador "desta cidade", i.e., do legislador das cidades existentes. ${ }^{55}$ A possibilidade de filosofia depende das cidades (deste mundo), as quais se opõem naturalmente à filosofia, logo, embora a

\footnotetext{
51 Farabi, Plato, §30.

52 Ibid., \$29.

53 Ibid., $\$ 30$.

${ }^{54}$ Ibid., $\$ 31$.

55 Ibid., 335 .
} 
realização da cidade justa seja possível ou conforme à natureza humana, ela parece ser, em todo o caso, extremamente improvável. Se a realização da cidade justa é quase impossível, o destino de Sócrates reflectirá, grosso modo, o destino da filosofia política neste mundo. A insuficiência da arte de Sócrates é, entre outras coisas, uma insuficiência política: ela não assegura as condições políticas indispensáveis ao seu exercício.

Talvez sem darmos conta disso, pois Strauss escreve de uma forma dialéctica sobre este assunto, a transição da arte de Sócrates para a arte de Platão já começou a ocorrer. A observação de que o destino de Sócrates não é acidental, mas praticamente uma necessidade, decorre da demonstração de que a cidade justa tem uma realização praticamente impossível neste mundo. Neste sentido, a ideia previamente mencionada de que para o Farabi de Strauss a discussão do destino de Sócrates está necessariamente ligada à questão da possibilidade de alcançar a felicidade começa a revelar a sua pertinência. Antes de analisarmos esta questão, será necessário compreender porque é que para o Farabi de Strauss a verdadeira felicidade consiste "in consideratione scientiarium speculativarum" em em "nada mais" (381).

No seu sumário sobre o Banquete de Platão, Farabi diz-nos que o verdadeiro prazer distingue-se do mero prazer na medida que aquele se origina na "perfeição desejada". Em bom rigor, esta ideia significa que o verdadeiro prazer não é idêntico à perfeição, mas antes que se origina no desejo de perfeição. ${ }^{56}$ Se no seu sumário sobre o Críton de Platão, Farabi admite a existência de "duas perfeições", também é verdade que no seu sumário sobre o Teeteto admite a existência de uma perfeição "mais elevada". ${ }^{57}$ Strauss interpreta a questão da relação entre a felicidade e a perfeição à luz da reflexão de Platão sobre o destino de Sócrates ou, como veremos mais adiante, à luz da relação entre a "filosofia" e a "arte real" (369). Seja como for, Strauss entende que quando menciona a "felicidade que lhe dá [ao homem] a sua perfeição ultima", Farabi estará a pensar no prazer que "acompanha" a "actualização da perfeição mais elevada do homem". Pois, segundo Strauss, é o "prazer que torna perfeito (teleiô̂) o exercício de uma faculdade" e, além disso, é um "prazer específico" conjuntamente com a perfeição mais elevada do homem que constituem a felicidade humana (385). Por prazer específico, Strauss entenderá o prazer próprio da actividade filosófica e por perfeição mais elevada Strauss entenderá, tal como Farabi, a filosofia. Mesmo admitindo que Timeu é feliz porque a sua arte é a filosofia, apenas Sócrates poderia saber que é feliz: tendo sophrosune, i.e., estando preocupado com os assuntos próprios da

\footnotetext{
56 Ibid., §18.

${ }^{57}$ Compare-se Ibid., $\$ 29$ com $\$ 3$.
} 
ciência política, Sócrates poderá investigar se o filósofo é verdadeiramente feliz e auto-percepcionar a sua felicidade.

Se apenas o filósofo pode ser verdadeiramente feliz, Strauss estaria correcto ao afirmar que os "não-filósofos são eternamente impedidos de alcançar a felicidade pela natureza das coisas" (381). Mas também parece resultar que nem os filósofos poderão ser felizes pelo simples factos de que não podem existir em "cidades imperfeitas", i.e., em cidades naturalmente opostas à filosofia. A impossibilidade de realizar a cidade justa acarreta $o$ encerrar da prospectiva de felicidade, não só para os não-filósofos, mas também para os filósofos (378): ninguém poderá ser verdadeiramente feliz neste mundo. Esta análise, viz., a análise da possibilidade de filosofia política, é uma análise própria da arte de Platão. Esta ideia é por sua vez dependente da ideia de que Platão, ao contrário de Sócrates, desenvolve uma profunda investigação sobre a relação entre a filosofia ou filósofo e a comunidade política. A arte de Platão, ao contrário da arte de Sócrates, investiga as condições políticas da prática filosófica. Neste sentido, a arte de Platão é mais propriamente ciência política do que a arte de Sócrates, a qual se cinge em grande medida ao problema político fundamental. Ao analisar a questão da relação entre o filósofo e a cidade, Platão estaria, entre outras coisas, a indagar as questões essencialmente práticas da possibilidade de filosofia e, por outro lado, da possibilidade de todo o homem ser feliz.

\section{A arte de Platão}

Strauss parece seguir Farabi ao distinguir entre Sócrates e Platão ou, nas palavras do próprio Strauss, entre a "atitude de Sócrates" e a "correcção" de Sócrates feita por Platão através dos seus diálogos ou, o que será equivalente, a "atitude de Platão" (382 e ss.). Efectivamente, tal como Strauss, Farabi distingue Platão de Sócrates ao enunciar o facto de Platão conjugar o "método" de Sócrates e o "método" de Trasímaco. ${ }^{58}$ Strauss entende que para Farabi a atitude política de Sócrates era determinada pelo facto de este "limitar a sua investigação aos assuntos morais e políticos". Neste sentido, Sócrates "negligenciava a filosofia natural" e era um "filósofo moral" ou "moralista". O facto de Sócrates negligenciar a filosofia natural parece estar de algum modo relacionado com o seu destino: a arte de Sócrates está na base da sua atitude política ou moral. $\mathrm{O}$ mesmo poderá ser dito no que diz respeito a Platão: se a sua arte fosse simplesmente idêntica à arte de Sócrates, ambos teriam o mesmo destino, i.e., o destino de Sócrates. Strauss aponta aquela que poderá ser a diferença

58 Ibid., $\$ 36$. 
decisiva entre Platão e Sócrates ao enunciar o facto de Platão considerar, por contraposição a Sócrates, a filosofia uma "ocupação essencialmente teórica". Neste sentido, Platão não seria um "moralista: o seu fervor moral era mitigado pela sua intelecção da natureza dos seres; assim, ele conseguia ajustar-se aos requisitos da vida política ou aos modos e opiniões dos vulgares. No tratamento dos assuntos em questão, ele combinou o modo de Sócrates e o modo de Trasímaco" (383).

Comecemos pelo princípio. Strauss parece identificar a diferença fundamental entre Sócrates e Platão no facto de Sócrates não conseguir intuir a natureza dos seres na mesma medida que Platão, o que terá determinado a atitude de Sócrates e, por conseguinte, levado à sua morte. Do mesmo modo que Strauss nunca diz que Platão elimina por completo o "fervor moral" e por isso o "moralismo" - o que dá a entender que a arte de Platão é também filosofia política ou que todo o diálogo platónico contém necessariamente a questão socrática -, também nunca afirma peremptoriamente que Sócrates rejeita a filosofia natural. Platão preserva o moralismo de Sócrates mas corrige-o através da arte de Trasímaco. A questão fundamental é, no entanto, a de saber qual é o tipo de conhecimento ou ciência que permitirá a Platão compreender a necessidade de corrigir a atitude de Sócrates e ao mesmo tempo preservar a filosofia política ou arte de Sócrates. Strauss diz explicitamente que Sócrates negligenciava a filosofia natural e, ao reconhecer que Platão mitigava o seu fervor moral através da intelecção da natureza dos seres, Strauss insinua que Platão corrigiu a atitude de Sócrates ao não negligenciar a filosofia natural. Qual é a "intelecção da natureza dos seres" que Strauss refere, mas não evidencia? Quais são os seres a que Strauss se refere?

A República é uma obra essencialmente platónica. Ao procurar conceber uma cidade justa ou perfeita para resolver o problema do destino de Sócrates, Platão teria de distinguir entre a mera justiça e a verdadeira justiça. Ao demonstrar que a verdadeira justiça é própria da cidade justa e que esta não pode existir "em actos", Platão obtém um conhecimento fundamental sobre a relação entre a filosofia e a cidade: a cidade mais conforme à natureza, a cidade natural, digamos assim, ou a cidade que mais verdadeiramente "é", embora seja conforme à natureza humana e por isso desejável, não pode muito provavelmente ser realizada. Isto significa que Platão descobre o facto de todas as cidades existentes serem imperfeitas e, até, o significado de elas serem imperfeitas, viz., o facto de elas serem naturalmente opostas à filosofia e, por isso, excluírem a verdadeira justiça. Podemos concluir, então, que a enigmática passagem de Strauss em que é afirmada a necessidade da intelecção da natureza dos seres para mitigar o fervor moral, significa, em bom rigor, que ao pensar as coisas humanas e políticas em função da sua absoluta conformidade 
com a natureza, coisas naturais ou seres, Platão consegue entender não só as coisas naturais, bem como os limites ou natureza das coisas políticas e humanas (sobre as coisas naturais veja-se 389-393).

\section{O exercício platónico da arte de Trasímaco}

Para Strauss é importantíssimo prestar atenção à forma como a discussão de Farabi sobre a relação entre a arte política e a filosofia vai evoluindo ao longo da Filosofia de Platão (366-388). Efectivamente Farabi parece separar num primeiro momento a filosofia da ciência política ${ }^{59}$, na medida em que seria preciso combinar as duas para produzir a verdadeira felicidade, mas, num segundo momento, parece "confundir" de algum modo essa separação ${ }^{60} \mathrm{e}$, num terceiro momento, a separação entre $\mathrm{o}$ filósofo e o político parece adquirir todo um novo sentido. ${ }^{61}$ A questão que Strauss levanta é: "porque é que, depois de ensinar que a filosofia precisa de ser suplementada por outra coisa para produzir felicidade, ele [Farabi] ensina que a filosofia não precisa de ser suplementada por outra coisa para produzir felicidade" (369). Já teremos observado que o Farabi de Strauss resolveria esta contradição ao distinguir a filosofia de Platão da verdadeira filosofia de Platão. O que ainda não analisámos foi a razão fundamental para Farabi proceder desse modo. A tese maior de Strauss é a de que a "relação da filosofia com a arte real está inseparavelmente ligada, no argumento de Farabi, à questão da relação da perfeição humana com a felicidade" (ibidem.). Noutra passagem (370), Strauss afirma peremptoriamente que Farabi identifica a filosofia com a arte real para "conduzir" o leitor através de um "engenho pedagógico" à ideia de que a "filosofia teórica" produz a verdadeira felicidade "nesta vida". Mas porque é que Farabi fará isso? Porque é que o Farabi de Strauss aplica o método de Trasímaco, tal como o Platão de Farabi? Como veremos o método de Trasímaco não é apenas uma defesa literária dos filósofos contra a cidade, mas também, e mais essencialmente, a forma verdadeiramente filosófica ou genuína da actividade filosófica.

Argumentaremos que Strauss explica o significado do método de Trasímaco recorrendo, em parte, ao próprio método de Trasímaco. O facto de Strauss expor o "verdadeiro" ensinamento do seu Farabi, tal como este havia feito em relação ao seu Platão, só compromete parte do esoterismo de Farabi. Como veremos, explicitar as ideias que estão na origem da escrita esotérica não elimina a possibilidade de escrita esotérica, pois, a

\footnotetext{
59 Veja-se, por exemplo, Plato, §2, §3, §4, §20 e $\$ 21$.

60 Veja-se, por exemplo, Ibid., §22.

61 Veja-se, por exemplo, Ibid., §31, §35 e §36.
} 
justificação última do verdadeiro esoterismo não recai sobre a possibilidade de perseguição política - a qual justificará a ocultação do verdadeiro ensinamento -, mas antes sobre a ideia de que apenas alguns homens conseguirão verdadeiramente compreender aquilo que é enunciado.

\section{Os heréticos}

O carácter "herético" da filosofia de Farabi e de Platão é explicado, segundo Strauss, pelo facto de que ambos se encontravam "sob compulsão" através dos poderes religiosos das suas respectivas cidades para "reconciliar" a doutrina filosófica de que a verdadeira felicidade corresponde à filosofia, por um lado, com a "crença na imortalidade da alma" e com os "requerimentos da fé", por outro (371). Para consolidar esta tese, Strauss sublinha primeiro que Farabi - revelando estar certamente familiarizado com a doutrina da imortalidade da alma noutras obras suas - omite esta doutrina no seu sumário da filosofia de Platão. Mais, omite-a até naqueles sítios onde seria suposto encontra-la, a saber, nos seus sumários do Fedro, Fédon e República. Esta omissão fez-se acompanhar, observa Strauss, do abandono de uma distinção recorrente nas obras de Farabi entre a felicidade neste mundo e no outro mundo. ${ }^{62}$ Strauss procura levar ao limite esta ideia ao afirmar que existe um profundo silêncio de Farabi sobre noûs e nô̂ no sumário de Farabi sobre a República; existe um contraste gritante entre aquelas obras em que Farabi se assume como autor dos ensinamentos que veicula e aquelas em que não o faz, sendo que nas primeiras transmite ensinamentos ortodoxos e nas últimas ensinamentos heréticos; Farabi opera uma tremenda depreciação da "especulação religiosa", "investigação religiosa dos seres" e da "arte religiosa do silogismo" (372-373). Poderíamos argumentar contra Strauss, no entanto, que Farabi desconhecia a doutrina da imortalidade da alma na filosofia de Platão, pelo que, ao estar meramente interessado em reproduzir a filosofia de Platão, essa reprodução seria sempre pouco fiel aos próprios ensinamento de Platão. O facto de Farabi ser um mau historiador não significa que ele seja um falso crente. Strauss contraria este tipo de objecção ao afirmar que "a República e as Leis" já haviam sido traduzidas no tempo de Farabi e que se encontravam à disposição deste (358). O melhor argumento que Strauss poderia usar contra a nossa objecção seria porém a de que Farabi parece discutir a República no seguimento da discussão acerca do destino de Sócrates e à luz da tentativa de encontrar uma cidade que seja favorável à filosofia. Farabi não é tão claro como Strauss em afirmar que a cidade justa é impossível, o que deixa margem para a

62 Attainment, §1. 
possibilidade de realizar a cidade justa neste mundo, como bem observa Christopher Colmo. ${ }^{63}$ Contra Colmo, no entanto, teremos de dizer que o próprio Farabi parece estar a formular um "modo" alternativo, i.e., o modo de Platão, o qual subsistirá até nas cidades imperfeitas - e neste aspecto Strauss parece ter razão. Mas para regressarmos à questão central, seria absurdo para Farabi admitir que Platão equacionara a cidade justa para Sócrates poder praticar a sua actividade se já acreditasse de antemão na possibilidade de o homem ser verdadeiramente feliz no outro mundo. Strauss pode estar correcto ao afirmar que Farabi rejeita a solução religiosa na Filosofia de Platão, mas isso provará, mais do que a heterodoxia de Farabi, a heterodoxia do Platão de Farabi.

Strauss defende-se desta objecção dizendo que custa a acreditar que Farabi procurasse reproduzir ensinamentos na qualidade de mero historiador que de outro modo rejeitaria "enquanto homem" (374). Mas dado que os ensinamentos de Platão são até "muito toleráveis", torna-se ainda mais curioso que Farabi tenha apresentando um Platão tão pouco literal. Strauss resolve este dilema afirmando que Farabi serve-se da "imunidade específica do comentador", de modo a transmitir o que realmente pensa relativamente ao seu estudo "histórico" sobre Platão. Dito de outra forma, Farabi serve-se de um estudo "histórico" para discutir a sua verdadeira filosofia. Esta é a forma como Strauss inverte a ordem hierárquica das obras de Farabi: a Filosofia de Platão será a obra que mais fielmente representa a filosofia de Farabi, mais até do que aquelas obras onde Farabi transmitiria os "seus" próprios ensinamentos (375). Todo o argumento de Strauss recolhe a sua força do facto de o contexto político de Farabi ser marcado pela Lei Divina e pela fé, as quais requererão a obediência dos cidadãos e a sua conformidade na adopção de opiniões ortodoxas ou, dito de outra forma, do facto de Farabi estar sob o risco de uma perseguição política de cariz religiosa, mas, ainda assim, deformar um ensinamento "bastante" ortodoxo transformando-o num ensinamento herético. Alguém poderia lembrar-se de argumentar, contra Strauss, que Farabi procuraria harmonizar Platão e Aristóteles para, com isso, demonstrar que ambos são heréticos. Mas Farabi diz claramente na introdução da Harmonização que procura remover dos "corações" daqueles que lêem os livros dos "filósofos" qualquer "dúvida e suspeita". ${ }^{64}$

Para Strauss, a questão do cariz herético da filosofia é, no pensamento de Farabi, a ilustração mais evidente de que o filósofo não pode presumir saber ou que não pode entender as coisas partindo de "opiniões pré-concebidas" sobre quais são as "coisas reais" que são "verdadeiramente

\footnotetext{
${ }^{63}$ Op. cit. pp. 974-975.

${ }^{64}$ Harmonization, $§ 1$.
} 
coisas reais", ou seja, que o filósofo não pode dar por garantida a existência de "substantie separatae" ou a diferença entre as "coisas divinas" e as "coisas naturais" (390-392): será por esta razão que a religião aparece aos olhos do filósofo "primeiro como um facto político", (372), i.e., como uma opinião, ou melhor, como um objecto da ciência política: a ciência política é por essência o domínio das opiniões.

\section{O esoterismo de Strauss e a razão fundamental do esoterismo do seu Farabi}

Reconhecer que o Platão de Farabi poderá representar, no grau mais elevado, a filosofia de Farabi não implica reconhecer que a própria filosofia de Platão é idêntica à filosofia do Platão de Farabi. Tendo em vista esta ideia, Strauss faz a curiosa observação de que Farabi considerava a sua versão da filosofia de Platão o "verdadeiro ensinamento" (376); neste sentido a Filosofia de Platão não seria um trabalho ou estudo histórico. Ainda mais curiosa é a observação de que Farabi seria por essa mesma razão um "verdadeiro platonista", pois, "o platonista não está preocupado com a verdade histórica (acidental)", mas com a "verdade filosófica (essencial)" (376-377). Strauss alude novamente ao perigo subjacente à prática da filosofia política ou da arte de Sócrates e, por conseguinte, à necessidade do "método de Trasímaco" ao explicar que "apenas por o discurso público exigir uma mistura de seriedade e comédia que o filósofo pode apresentar um ensinamento sério, o ensinamento filosófico sob uma capa histórica e, por então, cómica" (377). Como veremos, esta necessidade de mistura de seriedade e de comédia não deriva exclusivamente da ideia de perseguição religiosa.

A primeira razão aduzida por Strauss para explicar o esoterismo do seu Farabi está essencialmente ligada à ideia de heterodoxia religiosa. Como será evidente, a heterodoxia religiosa só constituirá um perigo para o filósofo enquanto os poderes religiosos, digamos assim, dispuserem de poder político ou, dito de outra forma, enquanto a perseguição política tiver, de algum modo, um cariz religioso. A primeira diferença evidente entre Strauss, por um lado, e Farabi e Platão, por outro, é a de que aquele não se encontra "sob compulsão" religiosa, pelo menos não certamente da mesma forma que aqueles se encontravam. Strauss assemelha-se mais ao seu Aristóteles do que ao seu Farabi (371). Será, no entanto, que poderemos dizer que Strauss não escreve de modo esotérico? Esta resposta é-nos dada pelo sentido último ou mais "convincente" do esoterismo do Farabi de Strauss. A razão mais convincente mostrará, ironicamente, que a razão menos convincente continua de algum modo viva até em cidades seculares, digamos assim. 
Strauss diz-nos que identificar a felicidade com a perfeição ou busca da perfeição seria equivalente a eliminar "a prospectiva de felicidade" da "larga maioria dos homens" (378). Por razões de "filantropia", o Farabi de Strauss seria "compelido" a distinguir a felicidade da perfeição. Esta afirmação de Strauss parece contradizer aquela outra em que reconhece que a verdadeira felicidade consiste na actualização das faculdades indispensáveis à perfeição humana (385). Esta aparente contradição é eliminada assim que tivermos em consideração o facto de Strauss se estar agora a referir à possibilidade de alcançar o "objectivo" da filosofia (381), viz., a ciência da essência de todas as coisas ou perfeição mais elevada e não à filosofia enquanto actualização da faculdade teórica. O mesmo será dizer, o Farabi de Strauss distingue a felicidade do alcançar de sabedoria de modo a criar a impressão de que a filosofia precisa de ser suplementada pela ciência ou arte política. Esta ideia encontraria a sua expressão mais acabada na ideia platónica de filósofo-rei ou na ideia de que o filósofo que é rei produz não só a sua felicidade, mas também a felicidades em todos os outros (378-379). ${ }^{65} \mathrm{~A}$ impossibilidade de realizar o governo dos filósofos nas cidades neste mundo constitui a impossibilidade de conduzir todo o homem "à felicidade". A razão última para o esoterismo é assim, segundo Strauss, a de que nem todos os homens poderão ser filósofos, perfeitos ou felizes. Se nem todos os homens podem ser filósofos significa que existem homens, a "larga maioria", que se contentam em viver com opiniões não-examinadas. Se a cidade justa não poder existir "em actos", toda a cidade imperfeita assenta necessariamente na opinião não-examinda, seja ela qual for - se a religião for de certa forma uma opinião insuficientemente examinada, há religião em toda a sociedade. Por esta razão fundamental, a actividade do filósofo é inevitavelmente "revolucionária" (383). ${ }^{66}$ A mera afirmação ou exposição desta ideia não conduz necessariamente os filósofos ao "perigo". O que conduz os filósofos ao perigo é a sua modalidade de discurso, i.e., a dialéctica ou discurso Socrático. Por outro lado, também poderemos dizer que direito qualquer à Filosofia é já uma forma de subversão da filosofia.

O "Farabi's Plato" é um texto profundamente dialéctico e, se Strauss estiver correcto, tal como a Filosofia de Platão. O leitor que os considere como simples tratados de filosofia fica com a impressão de que o seu sentido último não se desprendeu com a cronologia das palavras ou com uma mera leitura linear de princípio, meio e fim. O fim da leitura linear é o princípio da leitura dialéctica. A leitura dialéctica não é cronológica, é cumulativa ou progressiva. A cronologia das palavras não é necessa-

${ }^{65}$ Plato, $\$ 22$.

66 Ibid., $\$ 38$. 
riamente progressiva. Strauss segue o seu Farabi e o Platão de Farabi ao escrever de forma esotérica, não porque tenha explicitado que a felicidade é igual à filosofia, mas porque acreditar nesta ideia será muito diferente de compreendê-la:

"para ele [Strauss e Farabi] a filosofia é essencial e puramente teórica. É a forma de levar à ciência dos seres por distinção à ciência dos modos de vida. É a forma que leva a essa ciência mais do que essa ciência em si: é a investigação mais do que o resultado. A filosofia assim entendida é idêntica ao espirito científico 'em acção', a sképsis no sentido original do termo, i.e., à procura actual pela verdade que é animada pela convicção de que essa procura bastará a uma vida que merece ser vivida e que é fortificada pela desconfiança na propensão natural do homem para ficar satisfeito com convicções satisfatórias, ainda que não-evidentes ou não-provadas" (392-393 - o itálico é nosso). ${ }^{67}$

\section{Referências Bibliográficas:}

AVERROES, On Plato's Republic, Trans. Ralph Lerner, Cornell University Press, Ithaca, 1974.

COLMO, Christopher, "Theory and Practice: Alfarabi's Plato Revisited", The American Political Science Review, Vol. 86, No. 4, 1992, pp. 966-976.

FAKHRY, Majid, "The Ontological Argument in the Arabic Tradition: The Case of al-Farabi", Studia Islamica, No. 64, 1986, pp. 5-17.

FAKHRY, Majid, "Al-Farabi and the Reconciliation of Plato and Aristotle", Journal of the History of Ideas, Vol. 26, No. 4, 1965, pp. 469-478.

AL FARABI, On the Perfect State, trans. Richard Walzer, Oxford University Press, Oxford, 1985.

AL FARABI, Selected Aphorisms, trans. Charles Butterworth, Cornell University Press, Ithaca, 2001.

AL FARABI, Philosophy of Plato and Aristotle, trans. Muhsin Mahdi, Cornell University Press, Ithaca, 2001.

Al GHAZALI, The Incoherence of the Philosophers, trans. Micheal Marmura, Provo, Utah, 1997.

HEIDEGGER, Martin, The End of Philosophy, trans. Joan Stambaugh, University of Chicago Press, Chicago, 2003.

MAHDI, Muhsin, "Al-Farabi's Imperfect State”, Journal of the American Oriental Society, Vol. 110, No. 4, 1990, pp. 691- 726.

MAHDI, Muhsin, "The Editio Princeps of Farabi's Compendium Legum Platonis", Journal of Near Eastern Studies, Vol. 20, No. 1, 1961, pp. 1-24.

NAJJAR, Fauzi, "Farabi's Political Philosophy and shi'ism", Studia Islamica, No. 14, 1961, pp. 57-72.

${ }^{67}$ Compare-se Al Farabi ibid., 28 com Harmonization, $\$ 12$ e $§ 61$. Veja-se ainda, Attainment, §51, §55. 
RENAN, Ernest, “Averroès et l'Averroisme, Essai historique”, Oeuvres complètes de Ernest Renan, vol.3, Paris, 1949.

STRAUSS, leo, Philosophie und Gesetz: Beiträge zum Verständnis Maimunis und seiner Vorläufer, Berlin, Schocken Verlag, 1935.

STRAUSS, Leo, Natural Right and History, The University of Chicago Press, Chicago and London, 1965. Tradução portuguesa, M. MORGADO, Direito Natural e História, Edições 70, Lisboa, 2009.

STRAUSS, Leo, What is Political Philosophy? And Other Studies, the University of Chicago Press, Chicago, 1988.

STRAUSS, Leo, Thoughts on Machiavelli, University of Chicago Press, Chicago, 1978.

STRAUSS, Leo, Persecution and the Art of Writing, Glencoe, Ill., The Free Press, 1952.

STRAUSS, Leo, "Quelques remarques sur la science politique de Maïmonide et de Farabi”, Revue des Etudes Juives, 100, 1936, 1-37.

STRAUSS, Leo, "Farabi’s Plato", Louis Ginzberg Jubilee Volume, New York, American Academy for Jewish Research, 1945, pp. 357-393.

VELKLEY, Richard, Heidegger, Strauss, and the Premises of Philosophy, University of Chicago Press, London \& Chicago, 2011.

WALKER, Richard, "Platonism in Islamic Philosophy", Studia Islamica, No. 79, 1994, pp. 5-25. 